\title{
Efek Pelaparan dan Akumulasi Polifosfat terhadap Biopresipitasi Uranium pada Bacillus cereus A66
}

\author{
Bernadetta Octavia $^{1)^{*}}$, Triwibowo Yuwono ${ }^{2)}$, dan Agus Taftazani ${ }^{3)}$ \\ 1) Jurusan Pendidikan Biologi - Fakultas Matematika dan Ilmu Pengetahuan Alam, Universitas Negeri \\ Yogyakarta, Jl. Colombo No. 1, Karangmalang, Yogyakarta \\ ${ }^{2)}$ Fakultas Pertanian - Universitas Gadjah Mada, Jl. Flora, Bulaksumur, Sleman, Yogyakarta \\ ${ }^{3)}$ Pusat Sains dan Teknologi Akselerator - Badan Tenaga Nuklir Nasional, Jl. Babarsari, Sleman, Yogyakarta \\ ${ }^{*}$ Alamat korespondensi: dettac_via@yahoo.com
}

\begin{abstract}
ABSTRAK
Pelaparan dan akumulasi polifosfat pada bakteri diduga dapat meningkatkan biopresipitasi uranium. Tujuan penelitian ini adalah untuk mengetahui efek pelaparan dan akumulasi polifosfat terhadap peningkatan biopresipitasi uranium pada Bacillus cereus A66. Pada penelitian ini B. cereus A66 ditumbuhkan terlebih dahulu (prakultur) dalam Tryptone Glucose Yeast Extract (TGY), pada suhu ruang $\left( \pm 28^{\circ} \mathrm{C}\right)$ hingga fase logaritmik $( \pm 16 \mathrm{jam})$. Pada perlakuan pertama, prakultur B. cereus $\mathrm{A66}$ diberi perlakuan pelaparan fosfat dalam medium P-free, selanjutnya dipindahkan ke medium P-uptake untuk akumulasi fosfat. Untuk mengamati biopresipitasi uranium, sel bakteri dipindahkan ke dalam larutan uranium 1 mM. Pada perlakuan kedua, prakultur B. cereus A66 langsung dipindahkan ke dalam larutan uranium tanpa fase pelaparan dan akumulasi polifosfat. Sedangkan pada perlakuan ketiga, B. cereus A66 tanpa fase pelaparan dikultur dalam medium P-uptake kemudian dipindahkan ke larutan uranium. Pada perlakuan keempat, B. cereus A66 dikondisikan dengan pelaparan fosfat dalam medium P-free, diikuti dengan pemindahan ke dalam larutan uranium. Perlakuan kedua, ketiga dan keempat dirancang untuk mengkonfirmasi efek perlakuan pertama dalam penelitian ini. Hasil penelitian menunjukkan bahwa B. cereus A66 yang mengalami pelaparan fosfat dapat mengakumulasi fosfat delapan kali lebih banyak ketika dipindahkan ke medium P-uptake, dibandingkan dengan B. cereus A66 yang tidak mengalami pelaparan fosfat. Selain itu, B. cereus A66 yang mengakumulasi lebih banyak fosfat juga menunjukkan peningkatan biopresipitasi uranium sebesar 1,5 kali lebih banyak dibandingkan dengan $B$. cereus A66 yang tidak mengalami pelaparan fosfat. Fenomena ini diyakini digerakkan oleh metabolisme polifosfat yang dikontrol oleh aktivitas gen PPK dan PPX. Secara keseluruhan hasil penelitian ini menunjukkan bahwa semakin banyak polifosfat terakumulasi dalam sel, semakin meningkat respon biopresipitasi uranium dalam hal jumlah uranium yang diambil dari larutan dan efisiensi waktu pengambilannya. Strategi ini dapat dikembangkan lebih lanjut untuk bioremediasi air dan tanah yang terkontaminasi uranium.
\end{abstract}

Kata kunci: pelaparan polifosfat, biopresipitasi uranium, Bacillus cereus 


\title{
The Effect of Starvation and Polyphosphate Accumulation on Uranium Bioprecipitation in Bacillus cereus A66
}

\author{
Bernadetta Octavia $^{1)^{*}}$, Triwibowo Yuwono ${ }^{2)}$, dan Agus Taftazani ${ }^{3)}$ \\ 1) Biology Education Department - Faculty of Science dan Mathematics, Yogyakarta State University, \\ Jl. Colombo 1, Karangmalang, Yogyakarta \\ ${ }^{2)}$ Faculty of Agriculture -Gadjah Mada University, Jl. Flora, Bulaksumur, Sleman, Yogyakarta \\ ${ }^{3)}$ Center of Accelerator Science and Technology - National Nuclear Energy Agency, Jl. Babarsari, Sleman, \\ Yogyakarta \\ ${ }^{*}$ Email: dettac_via@yahoo.com
}

\begin{abstract}
Starvation and accumulation of polyphosphates in bacteria is thought to result in the improvement of uranium bioprecipitation. The purpose of this study was to prove the effect of starvation and polyphosphate accumulation in the improvement of uranium bioprecipitation in Bacillus cereus A66. B. cereus A66 was precultured in Tryptone Glucose Yeast Extract (TGY), at room temperature $\left( \pm 28^{\circ} \mathrm{C}\right)$ to logarithmic phase ( \pm 16 hours). In the first treatment, preculture of $B$. cereus A66 was subjected to phosphate starvation in P-free medium, followed by transferring to the P-uptake medium for phosphate accumulation. To observe the uranium bioprecipitation response, the bacterial cell was transferred to 1 $\mathrm{mM}$ uranium solution. In the second treatment, B. cereus A66 preculture was immediately transferred to the uranium solution with no starvation phase and accumulation of polyphosphate. Whereas in the third treatment, B. cereus A66 preculture without the starvation phase was cultured in the P-uptake medium and then transferred to uranium solution. In the fourth treatment, B. cereus A66 was conditioned with phosphate starvation in P-free medium, followed by transferring to uranium solution. The second, third and fourth treatments were designed to confirm the effect of the first treatment in this study. The results showed that B. cereus A66 subjected to phosphate starvation was able to accumulate phosphate eight times more when it was transferred to P-uptake medium, compared to B. cereus A66 which did not experience phosphate starvation. In addition, $B$. cereus $A 66$ which accumulated more phosphate also demonstrated an increase in uranium bioprecipitation as evidenced by 1.5 more uranium precipitated from the solution, compared to B. cereus A66 which was not subjected to phosphate starvation. This phenomenon was believed driven by polyphosphate metabolism controlled by the activity of the PPK and PPX genes. Overall, it was also shown that the more polyphosphate accumulated in cells, the more responsive uranium bioprecipitation in terms of uranium quantity being extracted from the solution and the efficiency of its uptake time. It is proposed that this strategy may be developed further for bioremediation of uranium-contaminated water and soil.
\end{abstract}

Keywords: polyphosphate starvation, uranium bioprecipitation, Bacillus cereus

\section{PENDAHULUAN}

Bakteri berinteraksi dengan uranium melalui mekanisme yang beragam seperti bioreduksi, bioakumulasi, biosorpsi, dan biopresipitasi [1,2]. Di antara mekanisme interaksi bakteri dengan uranium, immobilisasi uranium yang dimediasi fosfat merupakan strategi yang layak untuk sekuestrasi uranium dalam jangka panjang. Bioremediasi uranium yang dimediasi fosfat berkaitan dengan aktivitas hidrolase organofosfat dan metabolisme polifosfat pada bakteri [3]. Aktivitas hidrolase organofosfat merupakan proses biomineralisasi yang mengandalkan peran gen PhoN (gen fosfatase asam) dan gen PhoK (gen fosfatase alkali). PhoN merupakan periplasmic acid phosphatase, sedangkan PhoK merupakan extracellular alkaline phosphatase [4]. Aktivitas enzim fosfatase ini juga telah banyak diteliti pada beberapa bakteri seperti Escherichia coli, Pseudomonas aeruginosa, Serratia sp., dan Acinetobacter sp. Pada penelitian ini, immobilisasi uranium lebih diarahkan pada pemanfaatan metabolisme polifosfat bakteri. Konsep dasar pemanfaatan metabolisme polifosfat pada bakteri untuk immobilisasi logam dan radionuklida ini dipelajari melalui sistem EBPR (Enhanced Biological Phosphate 
Removal). Pada sistem ini terjadi degradasi dan pelepasan fosfat pada fase anaerob, sedangkan pengambilan fosfat dan perakitannya sebagai polifosfat pada fase aerob [9]. Dalam pendekatan biologis diketahui terdapat beberapa enzim yang berperanan dalam metabolisme polifosfat yaitu antara lain : polifosfat kinase (PPK), exopolifosfatase (PPX), endopolifosfatase, polifosfat glukokinase, dan polifosfat AMP fosfotransferase [10]. Pada E.coli, metabolisme polifosfat digerakkan oleh gen $p p k$ yang mengkatalisis polimerisasi ortofosfat intraselular dan gen $p p x$ yang mengkatalisis hidrolisis granula-granula polifosfat [3].

Di dalam lingkungan yang terkontaminasi logam dan radionuklida, ketersediaan nutrien rendah, serta adanya agenagen pengoksidasi, dan $\mathrm{pH}$ ekstrem yang menandakan cekaman kimiawi di lingkungan tersebut maka keadaan ini meningkatkan kesiagaan metabolisme mikrobia. Sebagai tanggapan terhadap lingkungan tersebut, produksi polifosfat intraselular oleh mikrobia merupakan salah satu cara untuk menangkap dan menyimpan/mendepositkan ion-ion toksik di dalam granula-granula polifosfat sitoplasma $[11,12]$. Beberapa penelitian telah dilakukan untuk mengatur metabolisme polifosfat agar dapat meningkatkan fungsinya dalam sekuestrasi logam dan radionuklida. Sebagai contoh eksperimen Van Veen et al [13] dilakukan dengan menumbuhkan Acinetobacter johnsonii 210A dalam medium $\mathrm{P} i$-free sehingga ketika dipindahkan dalam medium kaya $\mathrm{P} i$ maka terjadi peningkatan akumulasi Pi. Melalui penelitian ini $B$. cereus A66 dimanfaatkan untuk mengamati efek pelaparan dan akumulasi polifosfat terhadap peningkatan biopresipitasi uranium. Bakteri gram positif $B$. cereus A66 diisolasi dari limbah radioaktif cair aktivitas rendah yang dihasilkan oleh Pusat Sains dan Teknologi Akselerator, Badan Tenaga Nuklir Nasional, Yogyakarta [15].

\section{METODE PENELITIAN}

Perlakuan utama (perlakuan 1). Sel bakteri B.cereus A66 di tumbuhkan terlebih dahulu (prakultur) dalam $70 \mathrm{ml}$ medium TGY ( $1 \%$ bacto tryptone, $0,1 \%$ glucose, $0,5 \%$ yeast extract) [16] dengan digojog pada temperatur $28^{\circ} \mathrm{C}$ sampai fase logaritmik $( \pm 16$ jam $)$, kemudian OD diukur pada panjang gelombang $600 \mathrm{~nm}$ dan analisis konsentrasi fosfat dalam sel dilakukan menurut metode Saheki et al [17]. Selanjutnya, sel dipanen dengan cara disentrifus pada kecepatan $3000 \mathrm{rpm}$ selama 30 menit dan peletnya dicuci dengan $0,5 \mathrm{M}$ larutan $\mathrm{NaCl}$ lalu disentrifus lagi pada kecepatan $3000 \mathrm{rpm}$ selama 30 menit [14]. Pelet sel kemudian dikultur dalam medium untuk pelaparan fosfat menggunakan medium P-free $\left(\mathrm{CH}_{3} \mathrm{COONa} 5 \mathrm{~g}, \mathrm{MgSO}_{4} .7 \mathrm{H}_{2} \mathrm{O} 0,5 \mathrm{~g}\right.$, $\mathrm{KNO}_{3} 0,18 \mathrm{~g}$, trace elements $0,5 \mathrm{ml}, / 1, \mathrm{pH} 7$; Trace elements g/l: $\mathrm{FeCl}_{3} \cdot 6 \mathrm{H}_{2} \mathrm{O} 1,5 \mathrm{~g} ; \mathrm{H}_{3} \mathrm{BO}_{3}$ $0,15 \mathrm{~g} ; \mathrm{CuSO}_{4} \cdot 5 \mathrm{H}_{2} \mathrm{O} \quad 0,03 \mathrm{~g} ; \mathrm{KI} 0,18 \mathrm{~g}$; $\mathrm{MnCl}_{2} \cdot 4 \mathrm{H}_{2} \mathrm{O} 0,12 \mathrm{~g} ; \mathrm{Na}_{2} \mathrm{MoO}_{4} \cdot 2 \mathrm{H}_{2} \mathrm{O} 0,06 \mathrm{~g}$; $\mathrm{CoCl}_{2} \cdot 6 \mathrm{H}_{2} \mathrm{O}$ 0,12 g; EDTA $10 \mathrm{~g}, \mathrm{pH}$ 7) [18] . Kultur bakteri dalam $70 \mathrm{ml}$ medium P-free ini dikondisikan dalam keadaan statik [16] pada $28^{\circ} \mathrm{C}$, sampai tercapai kondisi lapar fosfat $\left(\mathrm{OD}_{600}= \pm 0,4\right)$ selama 24 jam (fase stasioner) [14]. Nilai $\mathrm{OD}_{600}$ dan kandungan fosfat dalam sel kemudian diukur. Pemanenan melalui sentrifugasi dilakukan lagi kemudian pelet sel dipindahkan ke dalam medium P-uptake $\left(\mathrm{CH}_{3} \mathrm{COONa} 5 \mathrm{~g}, \mathrm{MgSO}_{4} \cdot 7 \mathrm{H}_{2} \mathrm{O} 0,5 \mathrm{~g}, \mathrm{KNO}_{3}\right.$ $0,18 \mathrm{~g}, \mathrm{KH}_{2} \mathrm{PO}_{4} 0,25 \mathrm{~g}$, Pepton $0,5 \mathrm{~g}$, yeast extract $0,5 \mathrm{~g}$, trace elements $0,5 \mathrm{ml}, / 1, \mathrm{pH} 7$ ) [18] untuk mengukur akumulasi fosfat. Pengkulturan bakteri dalam $70 \mathrm{ml}$ medium Puptake ini digojog pada kecepatan $160 \mathrm{rpm}$, dan $28^{\circ} \mathrm{C}$ selama 24 jam (fase stasioner) [19]. Selanjutnya pengukuran $\mathrm{OD}_{600}$ dan analisis konsentrasi fosfat dalam sel dilakukan sebelum pemanenan pelet sel untuk dimasukkan ke dalam larutan uranil nitrat $1 \mathrm{mM}$. Kultur sel dalam larutan uranil nirat $1 \mathrm{mM}$ untuk eksperimen biopresipitasi uranium dikondisikan dalam keadaan statik pada $28^{\circ} \mathrm{C}$ [16]. Konsentrasi uranium tersisa dalam larutan, dan konsentrasi uranium di dalam sitoplasma sel diukur dengan metode yang telah dimodifikasi oleh Appukuttan et al [16], pada rentang waktu $0,3,6,12$ dan 24 jam.

Perlakuan kontrol (tiga perlakuan). Pada masing-masing perlakuan ini bakteri $\mathrm{B}$. cereus A66 ditumbuhkan terlebih dahulu (prakultur) dalam $70 \mathrm{ml}$ medium TGY (1\% bacto tryptone, $0,1 \%$ glucose, $0,5 \%$ yeast extract) [16] dengan digojog pada temperatur $28{ }^{\circ} \mathrm{C}$ sampai fase logaritmik $( \pm 16$ jam $)$. Semua perlakuan dalam eksperimen ini dilakukan dengan tiga ulangan. 
a) Perlakuan 2: prakultur bakteri B. cereus A66 dalam medium TGY langsung dipindahkan ke dalam larutan uranium 1 $\mathrm{mM}$ untuk analisis konsentrasi uranium. Pada perlakuan ini prakultur bakteri tersebut tidak mengalami fase pelaparan maupun akumulasi fosfat dalam medium $P$ uptake.

b) Perlakuan 3: prakultur bakteri B.cereus A66 dalam medium TGY dipindahkan ke dalam medium P-uptake tanpa diberi fase pelaparan. Selanjutnya dipindahkan ke dalam larutan uranium $1 \mathrm{mM}$ dan dilakukan analisis konsentrasi uranium. Melalui perlakuan ini diharapkan dapat diketahui efek pelaparan baik terhadap akumulasi polifosfat maupun biopresipitasi uranium.

c) Perlakuan 4: prakultur bakteri B.cereus A66 dalam medium TGY kemudian dipindahkan ke dalam medium P-free, selanjutnya dikulturkan dalam larutan uranium $1 \mathrm{mM}$. Perlakuan ini untuk menunjukkan peranan polifosfat intraselular dalam biopresipitasi uranium.

Penyiapan sampel bakteri untuk analisis SEM/EDX (Energy Dispersive X-Ray Spectroscopy). Analisis semi kuantitatif dengan melihat sel yang mengandung uranium melalui analisis EDX untuk memberi penegasan (konfirmasi) terhadap hasil analisis kimiawi kuantitatif tersebut. EDX ini merupakan bagian dari preparasi sel untuk SEM dan menggunakan alat yang sama dengan visualisasi SEM. Tahapan kerjanya diawali dengan melakukan mounting pellet sel bakteri pada suatu holder logam. Setelah itu dilakukan pengeringan dalam suatu alat vakum (Castable Vacuum System). Setelah sampel kering dilakukan coating dengan emas. Tahap terakhir adalah meletakkan holder yang berisi sampel kering pada alat Analytical Scanning Electron Microscope (JSM-6510 LA) yang sudah tersambung dengan komputer sehingga langsung dapat dilihat. Hasilnya berupa spektrum-spektrum yang menunjukkan elemen-elemen yang terkandung dalam sel bakteri tersebut.

\section{HASIL DAN PEMBAHASAN}

Efek pelaparan fosfat yang dilakukan terhadap sel bakteri Bacillus cereus A66 untuk meningkatkan biopresipitasi uranium ditampilkan pada Gambar 1a. Bakteri dari medium prakultur TGY yang dipindahkan ke dalam medium P-free mengalami penurunan fosfat yang drastis dalam selnya (keadaan lapar fosfat). Hal ini menunjukkan terjadinya hidrolisis polifosfat $\left[(\text { poli- } \mathrm{P})_{\mathbf{n}}+\mathrm{H}_{2} \mathrm{O} \rightarrow\right.$ (poli$\mathrm{P})_{\mathrm{n}-1}+\mathrm{P}_{i}$ ] dan selanjutnya $\mathrm{P} i$ dilepas ke luar sel sehingga sel mengalami phosphate starvation. Sel-sel yang dalam keadaan lapar fosfat ini selanjutnya dikultur dalam medium P-uptake. Perlakuan ini memberikan efek peningkatan akumulasi fosfat (dari kondisi fosfat dalam sel prakultur) sebesar 77,22\% (Gambar 1a), dibandingkan dengan yang tidak diberi perlakuan pelaparan fosfat (perlakuan 3) hanya meningkat sebesar 9,27\% (Gambar 3a).

Selanjutnya pada eksperimen biopresipitasi uranium, sel bakteri (Gambar 1a) yang pada awalnya mengandung fosfat intraselular sebesar $49,451 \quad \mu \mathrm{g} / \mathrm{ml}$ dapat mengambil uranium rata - rata sebesar $\pm 82,5 \%$ setelah 3 jam dalam larutan uranium $1 \mathrm{mM}$. Sel bakteri mengambil uranium terbanyak pada jam ke-6 yaitu sebesar 0,839 mM (83,9\%), sedangkan sel bakteri yang tidak diberi perlakuan pelaparan fosfat (Gambar 3a), mengambil uranium rata - rata sebesar $\pm 64,3 \%$ setelah 3 jam pada eksperimen yang sama.

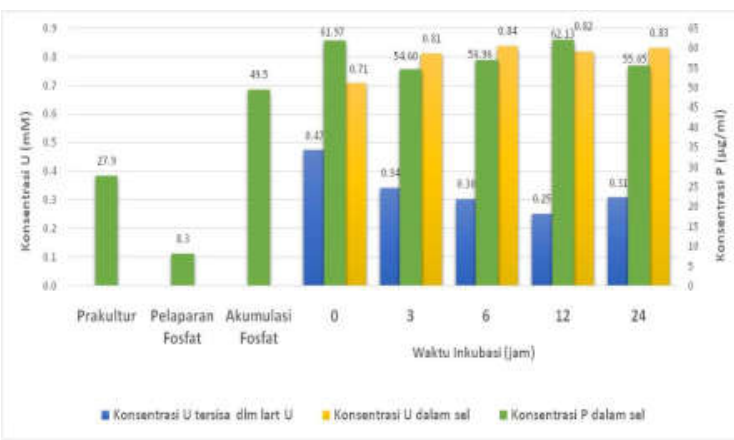

Gambar 1a. Perlakuan 1, biopresipitasi uranium dalam larutan uranil nitrat $1 \mathrm{mM}$ oleh B.cereus A66 yang telah dikultur dalam urutan medium : prakultur (TGY), pelaparan fosfat (P-free), dan akumulasi fosfat (P-Uptake) 


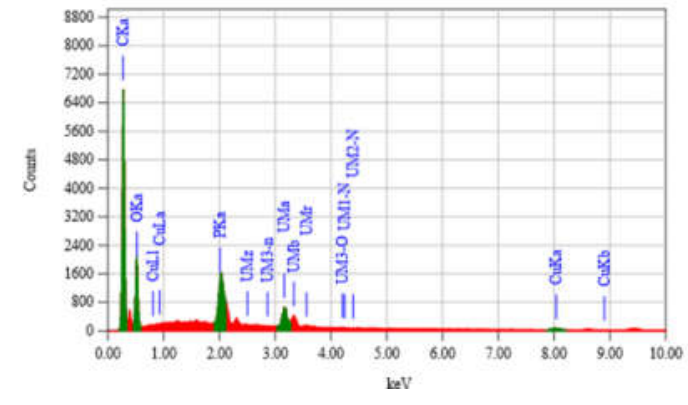

Gambar 1b. Spektra EDX dari sel yang mengandung uranium

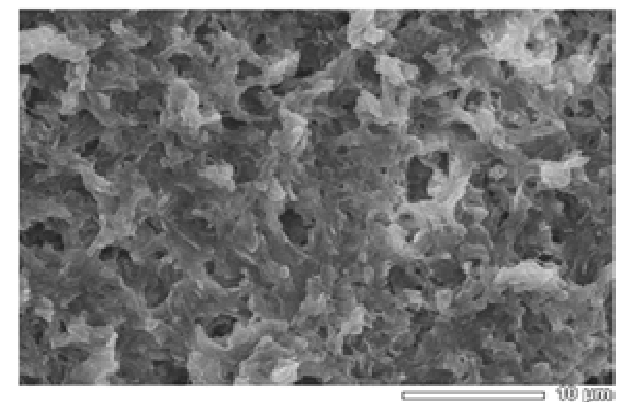

Gambar 1c. Microphotographs SEM sel bakteri yang mengandung uranium

Sel bakteri (Gambar 3a) mengambil uranium terbanyak pada jam ke 6 , sebesar $0,663 \mathrm{mM}(66,3 \%)$, sedangkan bakteri pada perlakuan 2 (Gambar 2a) mengambil uranium rata-rata sebesar $\pm 62,5 \%$ dan terbanyak pada jam ke-12 sebesar 0,659 mM (65,9\%). Selanjutnya, pada perlakuan 4 (Gambar 4a) sel bakteri yang telah mengalami phosphate starvation dalam medium P-free ditransfer ke dalam larutan uranium $1 \mathrm{mM}$. Konsekuensinya sel ini hanya mampu mengambil uranium rata - rata sebesar $\pm 31,2 \%$ setelah 3 jam. Pada perlakuan ini (Gambar 4a), sel bakteri mengambil uranium terbanyak sebesar 0,383 $\mathrm{mM}(38,3 \%)$ pada jam ke-24.

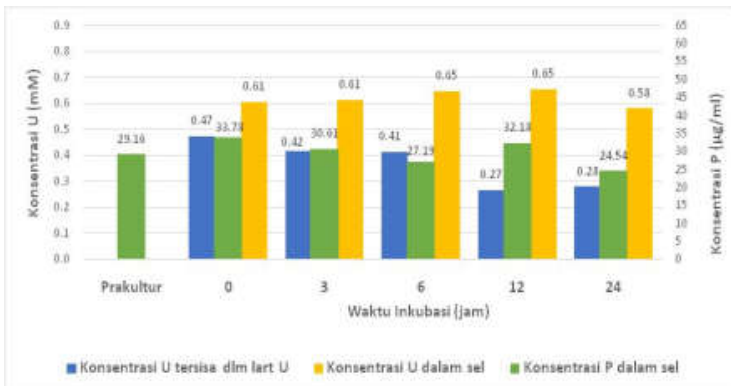

Gambar 2a. Perlakuan 2, biopresipitasi uranium dalam larutan uranil nitrat $1 \mathrm{mM}$ oleh $B$. cereus A66 yang berasal dari medium prakultur (TGY)

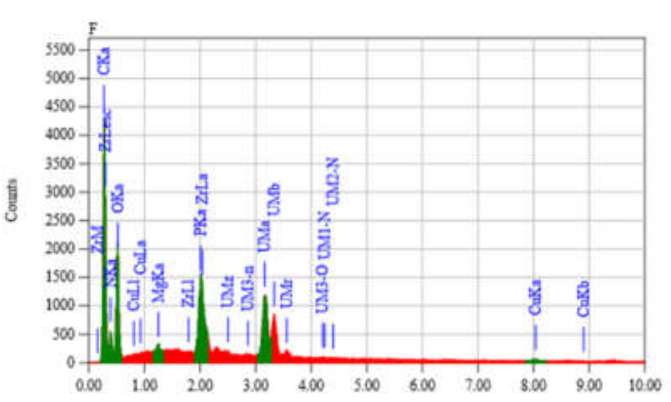

Gambar 2b. Spektra EDX dari sel yang mengandung uranium

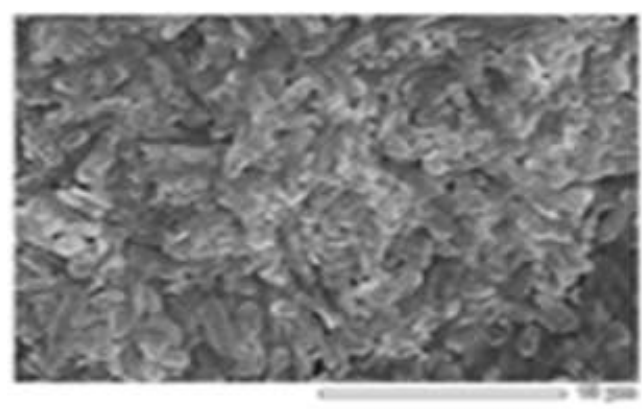

Gambar 2c. Microphotographs SEM sel bakteri yang mengandung uranium

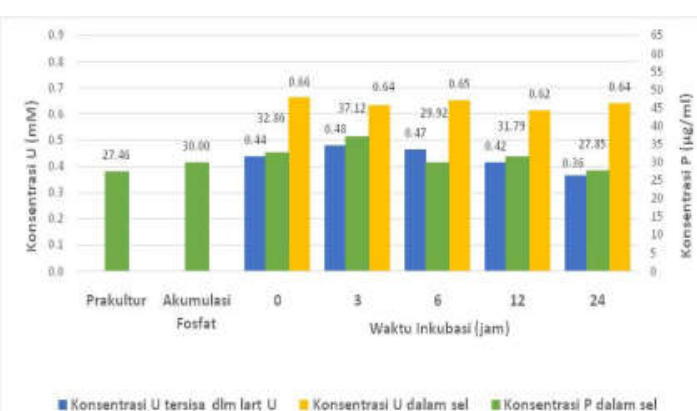

Gambar 3a.Perlakuan 3, biopresipitasi uranium dalam larutan uranil nitrat $1 \mathrm{mM}$ oleh B.cereus A66 yang telah dikultur dalam urutan medium : prakultur (TGY), dan akumulasi fosfat (P-uptake)

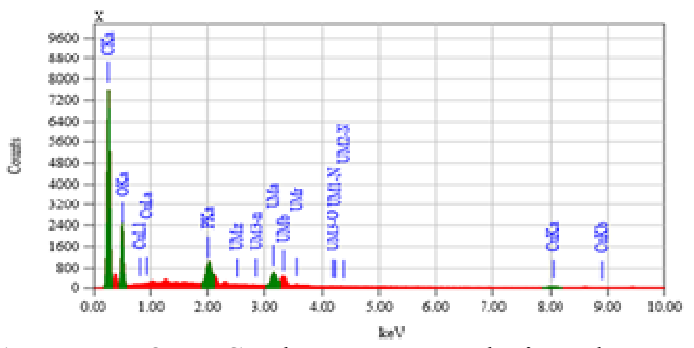

Gambar 3b. Spektra EDX dari sel yang mengandung uranium 


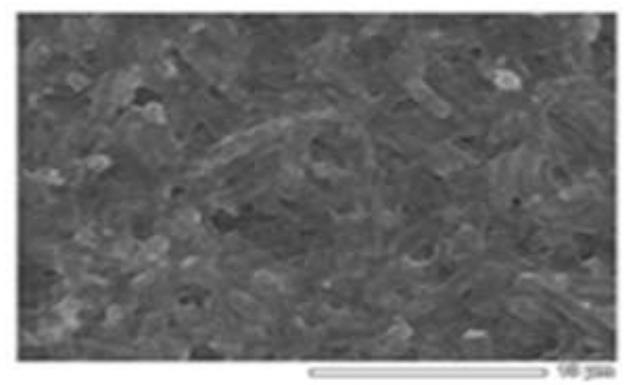

Gambar 3c. Microphotographs SEM sel bakteri yang mengandung uranium

Secara faktual hasil perlakuan pelaparan fosfat pada sel bakteri, selain dapat meningkatkan akumulasi fosfat, juga meningkatkan pengurangan uranium dari larutan. Jika pengurangan uranium ini dikaitkan dengan waktu maka perlakuan pelaparan fosfat pada sel bakteri juga meningkatkan efisiensi waktu pengambilan uranium. Ketika sel ditumbuhkan dalam medium P-free, maka konsentrasi $\mathrm{P}$ dalam sel berkurang drastis (sel lapar fosfat) (Gambar 1a dan 4a). Keadaan ini dapat terjadi karena adanya tekanan lingkungan yaitu tumbuh dalam kondisi tanpa fosfat, sehingga terjadi pelepasan fosfat oleh sel bakteri. Hal ini seperti yang terjadi pada eksperimen yang dijalankan oleh Gavigan et al [20]. Dalam hal ini sel bakteri dapat merilis fosfat karena dalam kondisi tekanan lingkungan tanpa fosfat ini telah menginduksi PPX sehingga terjadi hidrolisis cadangan polifosfat [21]. Dengan demikian maka terjadi penurunan konsentrasi $\mathrm{P}$ dalam sel secara signifikan. Selain memicu ekspresi gen PPX, kondisi tidak ada fosfat dalam medium (P-free) juga menginduksi gen PPK. Keadaan ini juga telah diamati oleh Trelstad et al [22] dan Geibdorfer et al [23] pada bakteri Acinetobacter sp. Strain ADP1 dalam riset pengembangan sistem EBPR. Disini mereka juga mendeteksi peningkatan jumlah transkrip gen PPK. Hal tersebut sesuai dengan hasil penelitian ini yaitu ketika sel bakteri ditumbuhkan dalam medium P-uptake, gen PPK sudah terinduksi dan mungkin juga sudah tersedia transkrip gen PPK. Oleh karena itu, ketika sel B. cereus A66 ditumbuhkan dalam medium P-uptake maka sel (Gambar 1a) dapat mengakumulasikan fosfat 8 kali lipat lebih banyak daripada sel yang tidak mengalami pelaparan fosfat. Data juga menunjukkan bahwa pada jam ke 6 (perlakuan utama) uranium berkurang 1,5 kali lipat lebih banyak.

Fenomena lain yang dapat diamati adalah bahwa keberadaan polifosfat intraselular memegang peranan kunci dalam pengurangan uranium dari larutan. Hal ini seperti yang dinyatakan oleh Martinez et al [3] bahwa keberadaan polifosfat sitosol memudahkan sekuestrasi logam-logam seperti $\mathrm{Cd}, \mathrm{Cu}, \mathrm{Hg}, \mathrm{Pb}, \mathrm{U}$, dan $\mathrm{Zn}$ pada beberapa strain bakteri hasil rekayasa genetika dan juga beberapa strain bakteri dan arkhaea di alam (wild strains). Pembuktiannya dapat dilihat pada sel bakteri perlakuan 1 dengan konsentrasi $\mathrm{P}$ intraselular tertinggi maka pengurangan uranium dari larutan juga tertinggi (Gambar 1a). Sebaliknya sel bakteri pada perlakuan 4 yang mengalami phosphate starvation dan dalam larutan uranium mempunyai konsentrasi $\mathrm{P}$ intraselular terendah hanya mampu mengambil uranium rata - rata sebesar $\pm 31,2 \%$, paling kecil dibandingkan dengan tiga perlakuan lain (Gambar 4a).

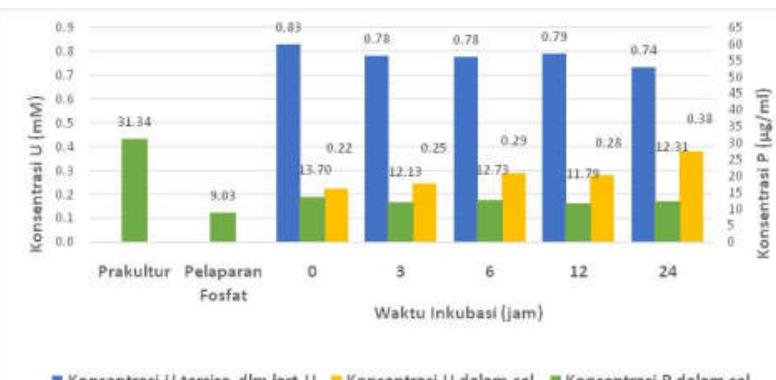

Gambar 4a. Perlakuan 4, biopresipitasi uranium dalam larutan uranil nitrat $1 \mathrm{mM}$ oleh B.cereus A66 yang telah dikultur dalam urutan medium : prakultur (TGY), dan pelaparan fosfat (P-free)

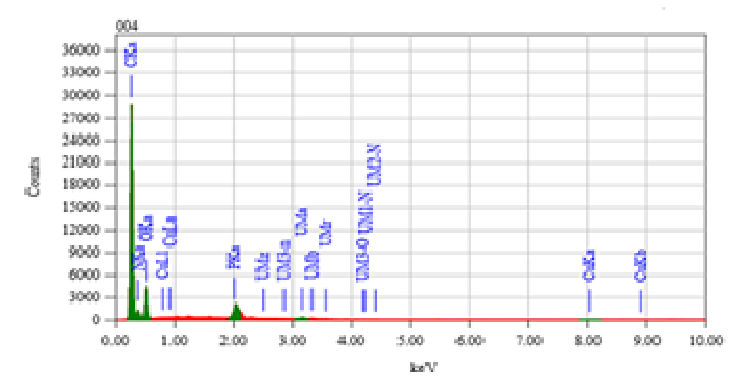

Gambar 4b. Spektra EDX dari sel yang mengandung uranium 


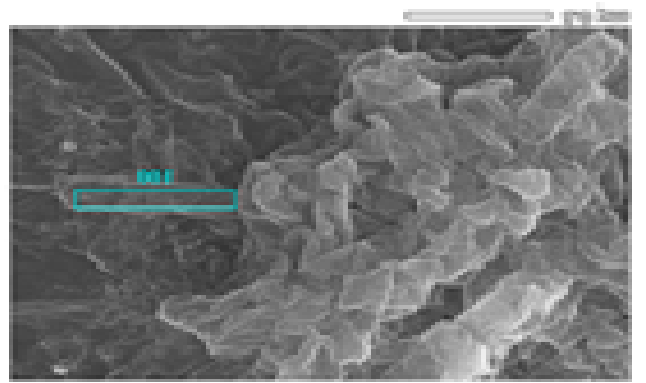

Gambar 4c. Microphotographs SEM sel bakteri yang mengandung uranium

Hasil analisis kimiawi kuantitatif tersebut juga terkonfirmasi oleh hasil analisis EDX terhadap sampel sel bakteri dari semua perlakuan. Secara semi-kuantitatif, analisis EDX menunjukkan spektrum uranium yang menguat pada perlakuan 1 (Gambar 1b) yang diwakili oleh sel bakteri yang mengambil uranium terbanyak rata-rata sebesar $\pm 82,5 \%$. Spektrum yang sangat lemah diwakili oleh sel bakteri pada perlakuan 4 (Gambar $4 \mathrm{~b}$ ) yang mengambil uranium rata-rata sebesar $\pm 31,2 \%$.

Beberapa penelitian yang dipublikasikan menyatakan bahwa $\mathrm{P} i$ hasil hidrolisis polifosfat akan disekresikan keluar sel sehingga dapat mempresipitasikan logam berat pada permukaan sel $[24,14]$. Akan tetapi dari hasil penelitian ini terdeteksi dalam larutan uranium sebagian besar P $i$ masih di dalam sel (Gambar $5 \mathrm{a}, 5 \mathrm{~b}, 5 \mathrm{c}$,dan 5d). Sesungguhnya uranium tidak mempunyai fungsi biologis di dalam sel. Jadi diduga uranium masuk ke dalam sel karena meningkatnya permeabilitas sel yang disebabkan toksisitas uranium [25]. Meskipun diduga terjadi peningkatan permeabilitas membran sel oleh toksisitas uranium, akan tetapi kemungkinan kondisi ini lebih cenderung dikendalikan oleh konsentrasi $\mathrm{P} i$ di dalam sel. Oleh karena itu apabila konsentrasi $\mathrm{P} i$ dalam sel rendah (Gambar 5d), maka uranium yang masuk ke dalam sel juga relatif sedikit. Sebaliknya kalau konsentrasi $\mathrm{P} i$ dalam sel tinggi (Gambar 5a, 5b, dan 5c), maka uranium yang masuk ke dalam sel juga relatif banyak. Kemungkinan model biokimia jalur hubungan antara konsentrasi $\mathrm{P} i$ dan transport uranium ke dalam sel melintasi membran sel dapat digambarkan melalui ilustrasi skematik pada Gambar 6a dan 6b.

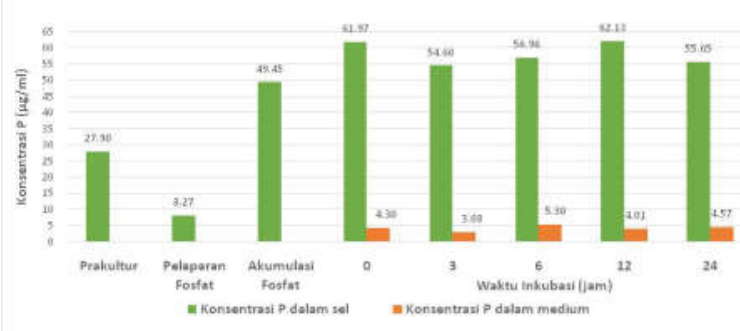

Gambar 5a. Perbandingan antara $\mathrm{P} i$ di dalam sel dan yang disekresikan ke dalam larutan uranium pada perlakuan 1

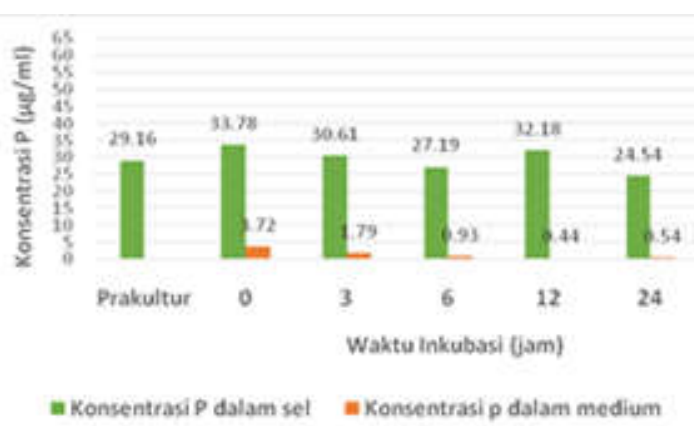

Gambar 5b. Perbandingan antara $\mathrm{P} i$ di dalam sel dan yang disekresikan ke dalam larutan uranium pada perlakuan 2

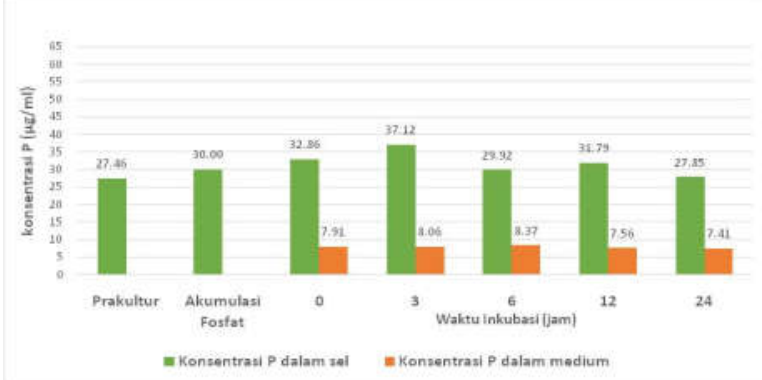

Gambar 5c. Perbandingan antara $\mathrm{P} i$ di dalam sel dan yang disekresikan ke dalam larutan uranium pada perlakuan 3

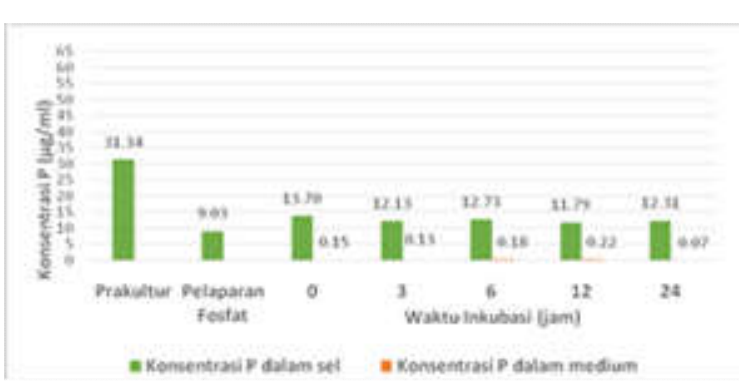

Gambar 5d. Perbandingan antara $\mathrm{P} i$ di dalam sel dan yang disekresikan ke dalam larutan uranium pada perlakuan 4 
Dalam larutan uranium, sel dikondisikan dalam keadaan statik. Selain itu tidak ada sumber karbon dan fosfat (Gambar 6b). Sel yang ditransfer ke dalam larutan uranium dari media P-uptake cukup banyak mengandung cadangan polifosfat. Dengan demikian membran sel ini juga cukup mempunyai proton motive force yang antara lain dihasilkan oleh ekskresi metal-fosfat (misal: $\mathrm{MgHPO}_{4}$ ) melalui symport system (Gambar 6b). Selanjutnya proton motive force ini dapat menggerakkan berbagai proses yang membutuhkan energi [26]. Sangat dimungkinkan bahwa ion uranil yang terdapat di luar sel terakumulasi di dalam sel melalui mekanisme proton-symport pump. Jadi mirip dengan mekanisme yang dilakukan sel bila mengambil elemen-elemen yang dibutuhkan oleh sel. Hal ini dinyatakan oleh Newsome et al [1] bahwa beberapa logam dapat masuk ke dalam sel melalui mekanisme "bioakumulasi' karena logam-logam tersebut mirip dengan logam-logam esensial yang dibutuhkan untuk fungsi seluler.

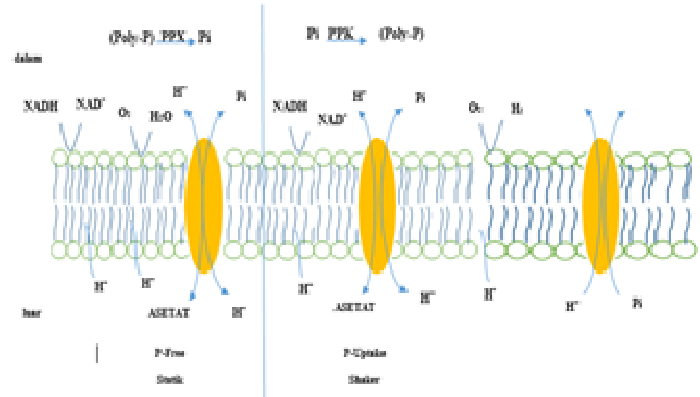

Gambar 6a. Model mekanisme transport $\mathrm{P} i$ dan ion uranil melintasi membran sel bakteri dalam medium P-free dan P-uptake

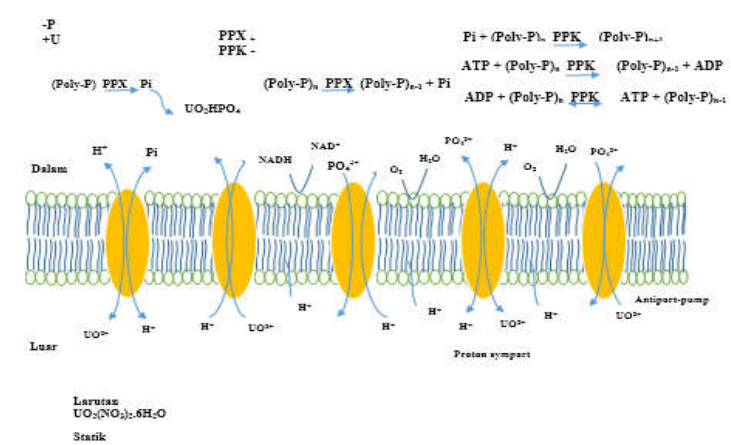

Gambar 7b. Model mekanisme transport $\mathrm{P} i$ dan ion uranil melintasi membran sel bakteri dalam larutan uranil nitrat
Cadangan polifosfat yang tinggi juga mengakibatkan lebih banyak $\mathrm{P} i$ yang disekresikan ke dalam larutan uranium. Sekresi $\mathrm{P} i$ melalui proton-symport system akan meningkatkan gradient proton transmembran [21]. Keadaan ini diduga dapat meningkatkan transport ion uranil ke dalam sel. Dengan demikian apabila cadangan polifosfat dalam sel makin banyak maka makin banyak pula ion uranil yang dapat ditransport ke dalam sel melalui mekanisme proton symport pump. Fenomena akumulasi uranium dalam sel ini mungkin juga berkaitan dengan $A B C$ transport systems yang terdapat baik pada bakteri Gram negatif maupun bakteri Gram positif [27]. $A B C$ transport systems ini terdiri dari periplasmic binding proteins, membrane transporter dan ATP-hydrolyzing proteins. ABC transport systems dapat dilihat pada Gambar 7.

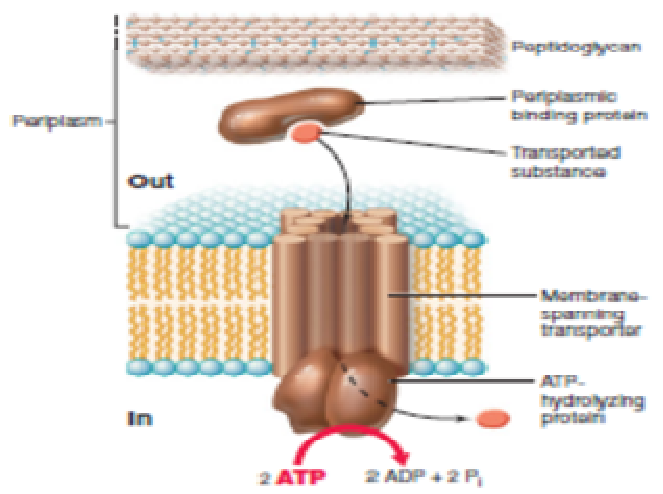

Gambar 7. Mekanisme pengambilan substrat melalui $A B C$ transporter [23].

Keberadaan $A B C$ transporter berfungsi untuk mengambil senyawa-senyawa organik seperti gula, asam amino, nutrien anorganik seperti sulfat dan fosfat, juga berbagai trace metal. Protein-protein $A B C$ transporter ini paling sedikit dikode oleh tiga macam gen. Gen-gen ini mungkin terekspresi oleh keberadaan $\mathrm{P} i$ di dalam sel. Aktivasi $A B C$ transporter ini oleh meningkatnya konsentrasi $\mathrm{P} i$ intraselular makin mempermudah uranium untuk masuk ke dalam sel dengan melalui mekanisme yang mirip dengan masuknya elemen-elemen yang diperlukan oleh sel. Kedua mekanisme transport tersebut yang diduga merupakan model mekanisme yang mendasari fenomena penelitian ini yaitu bahwa sel yang banyak mengakumulasikan fosfat juga banyak mengurangi uranium dari larutan. Sebaliknya yang sedikit mengandung 
fosfat dalam selnya juga hanya sedikit mengambil uranium dari larutan.

\section{KESIMPULAN}

Sel bakteri B. cereus A66 yang mengalami pelaparan fosfat mengakumulasikan lebih banyak fosfat daripada yang tidak dilaparkan fosfat dan berdampak terhadap peningkatan biopresipitasi uranium. Metode ini cukup layak dikembangkan untuk bioremediasi air dan tanah yang terkontaminasi uranium dengan beberapa perbaikan.

\section{DAFTAR PUSTAKA}

[1] Newsome, L., K. Morris, and J.R. Lloyd. 2014. The Biogeochemistry and Bioremediation of Uranium and Other Priority Radionuclids. Journal Chemical Geology, 363:164-184

[2] Merrour, M.L. and S. Selnska-Pobell. 2008. Bacterial Interaction With Uranium : An Environmental Perspective. Journal of Contaminant Hydrology, 102:285-295

[3] Martinez, R.J., M.J. Beazley, and P.A. Sobecky. 2014. Review Article : Phosphate - Mediated Remediation of Metals and Radionuclide, Advance in Ecology 2014:1-14. http; //dx.doi.org/10.1155/2014/7869 29).

[4] Kulkarni, S., C.S. Misra, A. Gupta, A. Ballai, and S.K. Apte. 2016. Interaction of Uranium with Bacterial Cell Surfaces: Inferences from Phosphatase-Mediated Uranium Precipitation. Applied and Environmental Microbiology. 82(16): $4965-4974$

[5] Macaskie, L.E., R.M. Empson, A.K Cheetham, C.P. Grey, A.I. Skarmulis. 1992. Uranium Bioaccumulation by A Citrobacter sp as a Result of Enzymically - Mediated Growth of Polycrystalline HUO2PO4. Journal Science. 257:782-784

[6] Macaskie, I.E. and A.C.R. Dean. 1982. Cadmium Accumulation by Microorganisms. Environmental Technology Letters. 3(2):49-56

[7] Macaskie, I.E. and A.C.R. Dean. 1985. Strontium Accumulation by
Immobilized Cells Of A Citrobacter sp. Biotechnology Letters. 7(9):627-630.

[8] Jeong, B.C., P.S. Poole, A.C.Willis, and I.E. Macaskie. 1998. Purification and Characterization of Acid Type Phosphatases from a Heavy Metal Accumulating Citrobacter sp. Archives of Microbiology. 169(2): 166-173

[9] Mino, T. 2000. Microbial Selection Of Polyphosphate - Accumulating Bacteria in Activated Sludge Waste Water Treatment Processes for Enhanced Biological Phosphate Removal. Biochemistry. 63(3): 341-348

[10] Miyake, T., T. Shiba, A. Kameda, Y. Ihara, M. Munekata, K. Ishige, and T Noguchi. 1999. The Gene for an Exopolyphosphatase of Pseudomonas aeruginosa. DNA Research. 6: 103-108

[11] Seufferheld, M.J., H.M. Alvarez, and M.F. Farias. 2008. Role of Polyphosphates in Microbial Adaptation to Extreme Environments. Applied and Environmental Microbiology. 74(19): 5867-5874

[12] Suzuki, Y. and J.F. Banfield. 2004. Resistance and Accumulation Of Uranium By Bacteria from a Uranium Contaminated Site. Journal Geomicrobiology. 21: 113-121

[13] Vanveen, H.W., T. Abee, G.J.J. Kortstee, W.N. Konings, and A.J.B. Zehnder. 1993. Characterization of Two Phosphate Tramsport Systems in Acinetobacter johnsonii 210A. Journal of Bacteriology. 175(1): 200-206

[14] Renninger, N., R. Knopp, H. Nitsche, D.S. Clark, and J.D Keasling. 2004. Uranyl Precipitation by Pseudomonas aeruginosa Via Controlled Polyphosphate Metabolism. Applied and Environmental Microbiology. 12(12): 7404-7412

[15] Octavia, B., T. Yuwono, and A. Taftazani. 2018. Isolasi dan Identifikasi Molekuler Bakteri Toleran Uranium yang Berpotensi dalam Biopresipitasi Uranium. Ganendra Journal of Nuclear Science and Technology. 21(1): 45-53

[16] Appukuttan, D., A.S. Rao, and S.K. Apte. 2006. Engineering of Deinococcus radiodurans R1 for Bioprecipitation of Uranium from Dilute Nuclear Waste. 
Applied and Environmental Microbiology. 72(12): 7873-7878

[17] Saheki, S., A. Takeda, and T. Shimazu. 1985. Assay of Inorganic Phosphate in the Mild $\mathrm{pH}$ Range, Suitable for Measurement of Glycogen Phosphorylase Activity. Analytical Biochemistry. 14: 277-281

[18] Aravind, J., T.Saranya, and P. Kanmani. 2015. Optimizing the production of polyphosphate from Acinetobacter towneri. Global Journal Environmental Science Manage. 1(1): 63-70.

[19] Rustrian, E., J.P. Delgenes, and R. Moletta. 1997. Phosphorus Release by Pure Cultures of Acinetobacter sp. : Effect of the Growth Stage with Cells Cultivated on Various Carbon Sources. Letters In Applied Micrbiology. 24: 144148

[20] Gavigan, J.A., L.M. Marshall, and A.D.W. Dobson. 1999. Regulation Of Plyphosphate Kinase Gene Expression In Acinetobacter baumanii 252. Microbiology. 145: 2931-2937

[21] Keasling, J.D., S.J. Van Dien, P. Trelstad, N. Renninger, and K. Mc. Mahon. 1999. Review: Application of Polyphosphate Metabolism to Environmental and Biotechnological Problems. Biochemistry. 65(3): 324-331

[22] Trelstad, P.L., P. Purdhani, W. Geibdorfer, W. Hillen, and J.D. Keasling,. 1999. Polyphosphate kinase of Acinetobacter sp. Strain ADP1: Purification and Characterization of the Enzyme and its Role during changes in extracellular phosphate levels. Applied and Environmental Microbiology. 65(9): 3780-3786

[23] Geibdorfer,W., A. Ratajczak, and W. Hillen. 1998. Transcription of ppk from Acinetobacter sp. Strain ADP1, Encoding a Putative Polyphosphate Kinase is induced by Phosphate Starvation. Applied and Environmental Microbiology. 64(3): 896-901

[24] Kulkarni,S., Misra, C.S., Gupta,A., Ballai, A., and Apte, S.K.2016. Interaction of Uranium with Bacterial Cell Surfaces: Inferences from Phosphatase-Mediated Uranium Precipitation. Applied and Environmental Microbiology. 82(16): 4965-4974

[25] VanVeen, H.W., Abee, Tj, Kortstee, G.JJ., Pereira, H., Konimgs, W.N., and Zehnder, A.J.B. 1994. Generation of a Proton Motive Force by the Excretion of Metal-Phosphate in the Polyphosphateaccumulating Acinetobacter johnsonii Strain 210A. The Journal of Biological Chemistry. 269(47): 29509-29514.

[26] Gavigan, J.A., Marshall, L.M., and Dobson, A.D.W. 1999. Regulation Of Plyphosphate Kinase Gene Expression In Acinetobacter baumanii 252. Microbiology. 145: 2931-2937 